\title{
JEKK
}

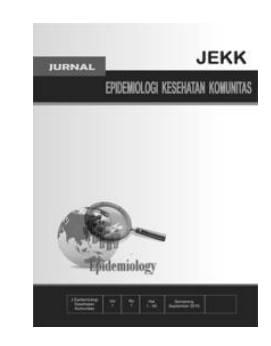

\section{Tempoyak Sebagai Faktor Risiko Kejadian Hipertensi (Studi pada Masyarakat Suku Dayak di Wilayah Puskesmas Tumbang Samba, Kabupaten Katingan, Kalimantan Tengah)}

\author{
Dwi Sutiningsih", Inova, ${ }^{* *}$ Mateus Sakundarno Adi ${ }^{*}$ \\ *Bagian Epidemiologi dan Penyakit Tropik, Fakultas Kesehatan Masyarakat Universitas Diponegoro, Semarang \\ ${ }^{* *}$ Magister Epidemiologi, Sekolah Pascasarjana, Universitas Diponegoro, Semarang
}

\begin{abstract}
Background: Tempoyak is a traditional food of Dayak tribe that is processed from durian fruit meat. Some studies show that at a certain amount of tempoyak consumption can increase blood pressure. Nutritional content in durian fruit that can affect blood pressure, namely, potassium, calcium, sodium, and alcohol. The purpose of this study is to prove that consuming tempoyak is a risk factor for hypertension.

Methods: This research is an observational research with cross sectional design that is done in Dayak tribal communities in the area of Tumbang Samba health center. The study population in this study is the population in the area of Puskesmas Tumbang Samba Katingan Regency. The sample number was 180 respondents who met the inclusion and exclusion criteria.

Result: The results showed that the proven factors for the incidence of hypertension are coffee consumption $(\mathrm{PR}=5,280 ; \mathrm{p}$-value=0.022), tempoyak consumption frequency $(\mathrm{PR}=3,935 ; \mathrm{p}=\mathrm{value}=0.047)$.

Conclusion : Tempoyak consumption is proven to be a risk factor for the incidence of hypertension.
\end{abstract}

Keywords: Tempoyak; hypertension; Dayak tribe.

*Penulis korespondensi, dwi.sutiningsih@live.undip.ac.id 


\section{Pendahuluan}

Hipertensi merupakan salah satu penyakit tidak menular yang saat ini masih menjadi masalah kesehatan di Indonesia yang harus diketahui oleh masyarakat umum karena gejalanya sering tanpa keluhan. Data Survei Indikator Kesehatan Nasional (Sirkesnas) tahun 2016 menunjukkan peningkatan prevalensi hipertensi pada penduduk usia 18 tahun ke atas sebesar 32,4. ${ }^{1}$ Jumlah penderita hipertensi di dunia terus meningkat setiap tahunnya, WHO memprediksi pada tahun 2025 akan ada 1,5 miliar orang yang terkena hipertensi. Diperkirakan juga setiap tahun ada 9,4 juta orang meninggal akibat hipertensi dan komplikasi. $^{2}$

Data Profil Kesehatan Provinsi Kalimantan Tengah tahun 2016 juga menunjukan prevalensi hipertensi pada penduduk yang berusia $\geq 18$ sebesar $24,79 \%$ $(76.168 \text { kasus })^{3}$. Data Profil Kesehatan Provinsi Kalimantan Tengah tahun 2017 juga menunjukkan adanya peningkatan kasus hipertensi pada penduduk yang berusia $\geq 18$ tahun sebesar 25,64\% (84.274 kasus). ${ }^{4}$ Dilihat dari data Profil Kesehatan Provinsi Kaimantan Tengah pada tahun 2015 sampai tahun 2017, kasus hipertensi di Provinsi Kalimantan Tengah mengalami peningkatan selama tiga tahun berturut-turut. Berdasarkan data dari dinas kesehatan kabupaten katingan di Puskesmas Tumbang Samba, prevalensi hipertensi tahun 2018 sebesar 1.309 kasus.

Tingginya prevalensi hipertensi di Kabupaten Katingan kemungkinan dipengaruhi oleh banyak faktor, salah satunya adalah jenis makanan yang dikonsumsi. Hal ini juga ditemukan pada masyarakat suku dayak di wilayah puskesmas Tumbang Samba. Jenis makanan khas tradisional di Katingan bersumber dari hasil perkebunan yang banyak dikonsumsi oleh masyarakat suku dayak salah satunya yaitu durian yang diolah menjadi Tempoyak.

Tempoyak merupakan makanan khas tradisional suku dayak yang diolah dari daging buah durian. Pada daging buah durian menunjukkan bahwa pada buah segar memiliki kadar air 56,32\%, kadar lemak 7,18\%, kadar protein $6,30 \%$, kadar serat kasar $10,19 \%$, kadar abu $1,30 \%$ dan kadar karbohidrat 10,98\%. Dari komposisi tersebut menunjukkan bahwa daging buah durian kandungan lemaknya cukup tinggi. Diketahui bahwa pada buah durian terdapat alkaloid harmane, jika dalam jumlah tertentu akan mampu meningkatkan tekanan darah. $^{5}$

Penambahan garam pada pembuatan tempoyak di masyarakat sangat bervariasi (2,5\%-30\%). Secara garis besar kandungan garam yang ditambahkan dapat menghasilkan 2 jenis tempoyak yang berbeda yaitu tempoyak asam kandungan garam yang ditambahkan kurang dari $5 \%$ dan tempoyak asin jika diberi penambahan garam lebih dari 5\%. Kandungan garam yang rendah akan lebih mendukung pertumbuhan bakteri asam laktat sehingga produk akhir mempunyai tingkat keasaman tinggi dalam waktu yang relatif lebih cepat dibandingkan dengan tempoyak yang diberi garam tinggi. Namun demikian, tempoyak yang dihasilkan dengan garam tinggi lebih awet dibandingkan dengan yang bergaram rendah. ${ }^{6}$

Masyarakat suku dayak biasanya mengkonsumsi tempoyak 2-3 kali seminggu bisa dicampurkan dengan bahan makanan yang akan dimasak dan ada juga yang langsung dimakan sebagai pengganti lauk ketika makan dengan jumlah yang dikonsumsi rata-rata 3-4 sendok makan sekali konsumsi. Dalam 1 sendok makan tempoyak mengandung rata-rata 2,5 gram garam. Hasil penelitiann yang dilakukan oleh Aufa juga menunjukkan dalam 1 sendok makan tempoyak mengandung 3 gram garam. $^{7}$

Hasil penelitian yang Resky dkk tentang studi penentuan nilai kalori pada buah durian menunjukkan hasil rata-rata kandungan kalori pada durian yaitu $186,38 /$ buah. $^{8}$ Khazanah( 2013) dalam program tayangan televisi juga mengatakan bahwa nilai kalori dalam buah durian sangat tinggi sehingga bersifat panas. Dalam buah durian juga terkandung alkohol. ${ }^{9}$ Peningkatan konsumsi alkohol baik itu diminum secara langsung atau yang terakandung dalam makanan akan meningkatkan angka kejadian tekanan darah tinggi. ${ }^{7}$

Terlalu banyak mengkonsumsi garam dapat meningkatkan tekanan darah hingga ke tingkat yang membahayakan. Pernyataan ini sesuai dengan hasil penelitian yang dilakukan 
oleh Aris Sugiharto (2007) yang menyatakan terdapat hubungan antara konsumsi asin dengan kejadian hipertensi tidak terkendali ( $\mathrm{p}=0,0001$, $\mathrm{OR}=3,95$ ). Konsumsi garam yang tinggi mempunyai risiko 3,95 kali lebih besar terjadi hipertensi tidak terkendali dibandingkan yang mengkonsumsi garam dalam jumlah normal. ${ }^{10}$

Konsumsi garam yang dianjurkan tidak lebih dari 6 gram per hari. ${ }^{11}$ Prevalensi hipertensi di Wilayah Puskesmas Tumbang Samba cukup tinggi namun sampai saat ini belum ada yang melakukan penelitian tentang beberapa faktor risiko makanan khas tradisional suku dayak yang berhubungan dengan kejadian hipertensi, sehingga menurut peneliti permasalahan ini sangat penting untuk dikaji.

\section{Metode}

Penelitian ini dilakukan pada masyarakat suku dayak di wilayah puskesmas Tumbang Samba Kabupaten Katingan. Penelitian dilakukan pada bulan Januari-Juni 2020. Penelitian ini merupakan penelitian observasional dengan menggunakan desain cross sectional. Populasi studi pada penelitian ini adalah penduduk yang ada di wilayah Puskesmas Tumbang Samba kabupaten Katingan. Sampel dalam penelitian ini yaitu warga yang di ada di wilayah puskesmas Tumbang Samba yang kemudian di pilih dari lima desa berbeda. Sampel yang dipilih yaitu warga yang berusia 18 tahun keatas dan merupakan asli suku dayak. Jumlah sampel dalam penelitian ini yaitu 180 sampel. Instrumen yang digunakan dalam penelitian ini adalah kuesioner yang yang sudah diuji sebelumnya kemudian dilanjutkan dengan pedekatan kualitatif melalui wawancara mendalam sebagai pelengkap kuantitatif dan tensimeter untuk meneliti variabel hipertensi. Analisis data menggunakan analisis univariat dan bivariat. Pengolahan data dalam penelitian ini diolah menggunakan SPSS 20

\section{Hasil}

Sampel penelitian yaitu warga suku dayak yang berada di wiayah puskesmas Tumbang Samba. Responden dalam penelitian ini sebanyak 180 orang, responden yang di ambil dari 6 desa berbeda di wilayah puskesmas Tumbang Samba dengan rincian hasil sebagai berikut: desa Samba Danum 45 responden, desa Samba Kahayan 35 responden, desa Samba Bakumpai 30 responden, desa Telok 20 responden, desa Tewang Panjang 15, desa Tumbang Lahang 35 responden

Tabel. 1 Distribusi responden penelitian

\begin{tabular}{lll}
\hline Variabel & Frekuensi \% \\
& & \\
\hline Kelompok umur & & \\
- 23-35 & 28 & $(15,6)$ \\
- 36-45 & 104 & $(57,8)$ \\
- 46-55 & 48 & $(26,7)$ \\
Kebiasaan minum alkohol & & \\
- Sering & 80 & $(44,4)$ \\
- Sedang & 66 & $(36,7)$ \\
- Jarang & 34 & $(18,9)$ \\
Kebiasaan minum kopi & & \\
- Ada & 124 & $(68,9)$ \\
- Tidak Ada & 56 & $(31,1)$ \\
Cara pengolahan tempoyak & & \\
- Secara Langsung & 38 & $(2,11)$ \\
- Dicampurkan & 142 & $(78,9)$ \\
Jumlah konsumsi & & \\
- Banyak & 92 & $(51,1)$ \\
- Sedang & 88 & $(48,9)$ \\
Frekuensi konsumsi & & \\
- Sering & 96 & $(53,3)$ \\
- Jarang & 84 & $(46,7)$ \\
Lama konsumsi & & \\
- >5 tahun & 144 & $(80,0)$ \\
- <5 tahun & 36 & $(20,0)$ \\
Jenis konsumsi & & \\
- dicampur & 151 & $(83,9)$ \\
- tidak dicampurkan & 29 & $(16,1)$ \\
Tekanan darah & & $(58,9)$ \\
Hipertensi & & $(41,1)$ \\
Tidak hipertensi & & \\
\hline & & \\
& &
\end{tabular}

Tabel 1 menunjukkan karakteristik responden menurut kelompok umur sebagian besar responden berusia 36-45 (57,8\%9), kebiasaan responden mengkonsumsi alkhol lebih sering $(44,4 \%)$ sedangkan sedang $(36,7 \%)$ dan yang jarang (18,9\%). Konsumsi kopi lebih sering $(68,9 \%)$, jarang $(31,1 \%)$. Cara pengolahan tempoyak, responden lebih sering memilih 
pengolahan dicampurkan dengan masakan lain $(78,9 \%)$ sedangkan yang tidak dicampurkan $(21,1 \%)$. Jumlah tempoyak yang dikonsumsi responden setiap kali yaitu lebih banyak $(51,1 \%)$ dan yang dalam jumlah sedang $(48,9 \%)$. Frekuensi seberapa sering responden mengkonsumsi tempoyak yaitu lebih sering $(53,3 \%)$ dan yang jarang $(46,7 \%)$. Responden yang sudah lama mengkonsumsi tempoyak $>5$ tahun yaitu $(80,0 \%)$ sedangkan yang $<5$ tahun $(20,0 \%)$. Jenis tempoyak yang sering responden konsumsi yaitu jenis yang dicampurkan dengan garam $(83,9 \%)$ sedangkan yang tidak dicampurkan garam $(16,1 \%)$. Distribusi

Tabel 2. Analisis bivariat variabel penelitian penderita hipertensi menurut pemeriksaan tekanan darah yang dilakukan pada saat penelitian menujukkan bahwa penderita hipertensi lebih banyak $(58,9 \%)$ dan yang tidak hipertensi $(41,1 \%)$.

\section{Kejadian hipertensi}

\begin{tabular}{lcccc}
\hline \multicolumn{1}{c}{ Variabel } & Ya (\%) & Tidak (\%) & Jumlah (\%) & p \\
\cline { 2 - 4 } Cara pengolahan & & & 0,888 \\
Secara langsung & $22(57,9 \%)$ & $16(42,1 \%)$ & $38(100 \%)$ & \\
$\begin{array}{l}\text { Dicampurkan } \\
\text { Jumlah konsumsi }\end{array}$ & $84(59,2 \%)$ & $58(40,8 \%)$ & $142(100 \%)$ & \\
Banyak & $58(63,0 \%)$ & $34(37,0 \%)$ & $92(100 \%)$ & 0,247 \\
Sedang & $48(54,5 \%)$ & $40(45,5 \%)$ & $88(100 \%)$ & \\
Lama konsumsi & & & & \\
$>5$ tahun & $86(59,7 \%)$ & $58(40,3 \%)$ & $144(100 \%)$ & \\
$<5$ tahun & $20(50,6 \%)$ & $16(44,4 \%)$ & $36(100 \%)$ & \\
Frekuensi & & & $96(100 \%)$ & \\
konsumsi & $50(52,1 \%)$ & $46(47,9 \%)$ & $84(100 \%)$ & \\
Sering & $56(66,7 \%)$ & $28(33,3 \%)$ & & \\
Jarang & & & \\
Jenis tempoyak & $91(60,3 \%)$ & $60(39,7 \%)$ & $29(100 \%)$ & 0,392 \\
Ada & $15(51,7 \%)$ & $14(48,3 \%)$ & \\
Tidak & & & \\
\hline
\end{tabular}

Tabel 2 menunjukkan responden yang mengolah tempoyak secara langsung maupun dicampurkan dengan masakan lain tidak meningkatkan risiko hipertensi. Responden yang mengkonsumsi tempoyak baik dari tingkat banyak maupun sedang tidak merupakan faktor risiko kejadian hipertensi. Dilihat dari frekuensi seberapa sering responden mengkonsumsi tempoyak didapatkan hasil bahwaresponden yang sering mengkonsumsi tempoyak 1-3 $\mathrm{kali} /$ minggu atau setiap hari merupakan faktor risiko kejadian hipertensi. Hasil analisis berdasarkan lama mengkonsumsi tempoyak didapatkan bahwa tidak ada yang signifikan secara statistik. Berdasarkan jenis tempoyak yang dikonsumsi didapatkan hasil bahwa jenis tempoyak yang dicampurkan dengan garam dan yang tanpa garam tidak menunjukkan hasil yang signifikan secara statistik. Kebiasaan konsumsi minum kopi responden penelitian dengan kejadian hipertensi didapatkan hasil yang signifikan. responden yang memiliki kebiasaan 
minum kopi 1-2 cangkir per hari meningkatkan risiko hipertensi dibanding responden yang tidak memiliki kebiasaan minum kopi.

\section{Pembahasan}

Dari hasil analisis yang dilakukan menujukkan bahwa terdapat hubungan yang bermakna antara frekuensi konsumsi tempoyak terhadap kejadian hipertensi, diperoleh nilai $\mathrm{p}=0,047, \mathrm{RP}=3,935$, dan nilai $\mathrm{df}=1$. Karena nilai $\mathrm{p}=0,047<0,05=\alpha$, maka $\mathrm{H}_{0}$ ditolak dan $\mathrm{H}_{\mathrm{a}}$ diterima. Artinya terdapat hubungan yang bermakna antara frekuensi konsumsi tempoyak dengan kejadian hipertensi. Kandungan gizi dalam buah durian yang dapat mempengaruhi tekanan darah yaitu, kalium, kalsium, sodium, dan alkohol. Kalium berpengaruh terhadap pompa jantung. Kelebihan kalium dalam cairan ekstraselular akan menyebabkan jantung menjadi sangat mengembang dan lemah serta frekuensi denyut jantung menjadi lambat. ${ }^{12}$ Jumlah kalium yang terlalu besar juga akan menghambat penjalaran impuls jantung yang berasal dari atrium menuju ventrikel melalui berkas A-V (AV node). Sementara kalsium memiliki efek berlawanan terhadap kalium, kelebihan jumlah kalsium dalam darah akan menyebabkan jantung berkontraksi secara spastis. Hal ini disebabkan oleh pengaruh langsung kalsium dalam membangkitkan proses kontraksi jantung. ${ }^{12}$

Dari hasil penelitian yang dilakukan pada 180 responden di wilayah puskesmas Tumbang Samba didapatkan hasil bahwa responden yang sering mengkonsumsi tempoyak merupakan faktor terhadap kejadian hipertensi. Hal ini menunjukkan bahwa sering mengkonsumsi makanan asin atau konsumsi tempoyak kemungkinan merupakan faktor risiko terhadap kejadian hipertensi pada masyarakat suku dayak di wilayah Puskesmas Tumbang Samba. Hal ini juga sejalan dengan pendapat pakar, asupan garam kurang dari 3 gram/hari tidak menyebabkan prevalensi hipertensi meningkat sedangkan asupan garam 5-15 gram/hari menyebabkan prevalensi hipertensi meningkat menjadi $15-20 \%$. Pengaruh asupan terhadap hipertensi terjadi melalui peningkatan volume plasma, curah jantung dan tekanan darah. Garam menyebabkan penumpukan cairan dalam tubuh, karena menarik cairan diluar sel agar tidak keluar, sehingga meningkatkan volume dan tekanan darah. ${ }^{13}$ Hasil penelitian yang juga dilakukan oleh Susi (2017) menunjukkan bahwa kandungan lemak dalam daging buah durian cukup tinggi. ${ }^{14}$ Konsumsi lemak secara berlebihan dalam makanan dapat berisiko kegemukan atau kolestrol dalam darah yang berkaitan dengan kenaikan tekanan darah. ${ }^{13}$

\section{Kesimpulan}

Frekuensi konsumsi tempoyak merupakan faktor risiko terhadap kejadian hipertensi. Lama konsumsi tempoyak, jenis tempoyak yang dikonsumsi bukan merupakan faktor risiko terhadap kejadian hiprtensi.

\section{Ucapan Terima Kasih}

Penulis mengucapkan terima kasih kepada seluruh responen masyarakat Suku Dayak di wilayah Puskesmas Tumbang Samba atas partisipasinya dalam penelitian ini.

\section{Daftar Pustaka}

1. Badan Penelitian Dan Pengembangan Kesehatan. 2016. Laporan Survei Indikator Kesehatan Nasional. Kementrian kesehatan RI.

2. World Health Organization. World Health Statistics 2015. 2015. World Health Organization, editor. Geneva: World Health Organization.

3. Profil Kesehatan Provinsi Kalimantan Tengah. 2016. Dinas Kesehatan Provinsi Kalimantan Tengah.

4. Profil Kesehatan Provinsi Kalimantan Tengah. 2017. Dinas Kesehatan Provinsi Kalimantan Tengah.

5. Harli, M. dan N. Arfiansyah. Jangan Sembarangan Makan Durian. 2000. Majalah trubus. Jakarta., NO.363. Edisi Februari TH. XXXI 
6. Yuliana, N. Murhadi. Dan Zuidar, A.S. 2005. Produksi Tempoyak Secara Terkontrol Menggunakan Pediococcus acidilacticiae sebagai Starter. Universitas Lampung: Laporan Penelitian RG-TPSDP.

7. Aufa Haryani. 2009. Pengaruh Konsentrasi Garam Dan Suhu Fermentasi Terhadap Karakteristik Tempoyak Durian .

8. Resky Perdana Yanti, Muh. Said L. \& Ihsan. 2014. Studi Penentuan Nilai Kalori Pada Buah Durian (Durio Zibethinus). UIN Alauddin Makassar.

9. Khazanah. Khasiat Buah Berbau Tajam. Liputan Trans 7. Januari 2017

10. Aris, Sugiharto. 2007. Faktor Risiko Hipertensi Grade II Pada Masyarakat [Tesis], Program Studi Magister Epidemiologi Program Pasca Sarjana Universitas Diponegoro Semarang.

11. Depkes RI. 2006. Pedoman Teknis Penemuan Dan Tatalaksana Penyakit Hipertensi. Direktorat P2PL: Jakarta.

12. Guyton AC, Hall JE. 1997. Fisiologi kedokteran. 9th ed. Jakarta: EGC. Hal 148,193-194,299-301.

13. Sheps SG. 2005. Mayo Clinic Hipertensi: Mengatasi Tekanan Darah Tinggi. Intisari Mediatama: Jakarta.

14. Susi. 2017. Identifikasi Komponen Kimia Dan Fitokimia Durian Lahung (Durio Dulcis) Indigenous Kalimantan. Fakultas Pertanian, Universitas Lambung Mangkurat Banjarbaru. Al Ulum Sains dan Teknologi Vol. 3 No. 1 Nopember 2017. 